\title{
CXCR4 Antagonists as Stem Cell Mobilizers and Therapy Sensitizers for Acute Myeloid Leukemia and Glioblastoma?
}

\author{
Vashendriya V.V. Hira ${ }^{1, *}$, Cornelis J.F. Van Noorden ${ }^{1,2}$ (I) and Remco J. Molenaar ${ }^{1,3}$ \\ 1 Department of Genetic Toxicology and Cancer Biology, National Institute of Biology, 1000 Ljubljana, \\ Slovenia; c.j.vannoorden@nib.si (C.J.F.V.N.); r.j.molenaar@amsterdamumc.nl (R.J.M.) \\ 2 Department of Medical Biology, Cancer Center Amsterdam, Amsterdam UMC at the Academic Medical \\ Center, 1105 AZ Amsterdam, The Netherlands \\ 3 Department of Medical Oncology, Cancer Center Amsterdam, Amsterdam UMC at the Academic Medical \\ Center, 1105 AZ Amsterdam, The Netherlands \\ * Correspondence: vashendriyavvhira@gmail.com
}

Received: 31 December 2019; Accepted: 12 February 2020; Published: 17 February 2020

\begin{abstract}
Glioblastoma is the most aggressive and malignant primary brain tumor in adults and has a poor patient survival of only 20 months after diagnosis. This poor patient survival is at least partly caused by glioblastoma stem cells (GSCs), which are slowly-dividing and therefore therapy-resistant. GSCs are localized in protective hypoxic peri-arteriolar niches where these aforementioned stemness properties are maintained. We previously showed that hypoxic peri-arteriolar GSC niches in human glioblastoma are functionally similar to hypoxic peri-arteriolar hematopoietic stem cell (HSC) niches in human bone marrow. GSCs and HSCs express the receptor C-X-C receptor type 4 (CXCR4), which binds to the chemoattractant stromal-derived factor- $1 \alpha$ (SDF- $1 \alpha$ ), which is highly expressed in GSC niches in glioblastoma and HSC niches in bone marrow. This receptor-ligand interaction retains the GSCs/HSCs in their niches and thereby maintains their slowly-dividing state. In acute myeloid leukemia (AML), leukemic cells use the SDF-1 $\alpha-C X C R 4$ interaction to migrate to HSC niches and become slowly-dividing and therapy-resistant leukemic stem cells (LSCs). In this communication, we aim to elucidate how disruption of the SDF- $1 \alpha-C X C R 4$ interaction using the FDA-approved CXCR4 inhibitor plerixafor (AMD3100) may be used to force slowly-dividing cancer stem cells out of their niches in glioblastoma and AML. Ultimately, this strategy aims to induce GSC and LSC differentiation and their sensitization to therapy.
\end{abstract}

Keywords: Glioblastoma; glioblastoma stem cells; niches; acute myeloid leukemia; hematopoietic stem cells; bone marrow; C-X-C receptor type 4; stromal-derived factor- $1 \alpha$; plerixafor

Glioblastoma (World Health Organization grade IV glioma) is the most aggressive and lethal primary brain tumor in adults, with a poor survival of only 20 months after diagnosis despite surgery, radiotherapy, temozolomide chemotherapy and magnetic tumor-treating fields (TTF) in the fittest patient population [1-5]. This poor patient survival is at least partly caused by glioblastoma stem cells (GSCs) that reside in protective niches where they are maintained as slowly-dividing and therapy-resistant cells [6-9]. Various cell types and tissue structures in the tumor microenvironment enforce the stem cell characteristics on GSCs. These microenvironmental cues enable GSCs to adapt to changing circumstances in the tumor and, as a consequence, GSCs are maintained as quiescent and therapy-resistant cells [10,11].

In our previous studies, we provided evidence that GSC niches in human glioblastoma tumors are functionally similar to hematopoietic stem cell (HSC) niches in normal human bone marrow $[12,13]$. 
Both GSC niches and HSC niches are hypoxic and peri-arteriolar where the GSCs/HSCs are localized adjacent to the tunica adventitia of the arteriolar wall $[8,12,14,15]$. The chemoattractant stromal-derived factor- $1 \alpha$ (SDF-1 $\alpha$; also known as CXCL12) is abundantly expressed in GSC/HSC niches for homing of C-X-C receptor type 4 (CXCR4)-positive GSCs/HSCs in their niches $[8,12,14,15]$. Hypoxia is crucial for the maintenance of slowly-dividing GSCs/HSCs in niches. The transcription factors hypoxia-inducible factor- $1 \alpha$ (HIF- $1 \alpha)$ and HIF- $2 \alpha$ are highly expressed in niches and in turn upregulate expression of stem cell genes, such as CD133 and sex-determining region Y-box factor 2 (SOX2) for GSCs, and CD133 and CD150 for HSCs [12]. In addition, hypoxia upregulates the expression of SDF- $1 \alpha$ and its receptor CXCR4 in glioblastoma tumors and bone marrow via HIF-1 $\alpha$ [9,15-19]. In Figure 1, a peri-arteriolar HSC niche in bone marrow (Figure 1A,B) and a peri-arteriolar GSC niche in a glioblastoma tumor (Figure 1C,D) are shown. HSCs and GSCs express the stem cell marker CD133 and the SDF-1 $\alpha$ receptor CXCR4. The GSCs/HSCs are localized around smooth muscle actin-positive arterioles in niches that contain extracellular SDF-1 $\alpha$ [12].

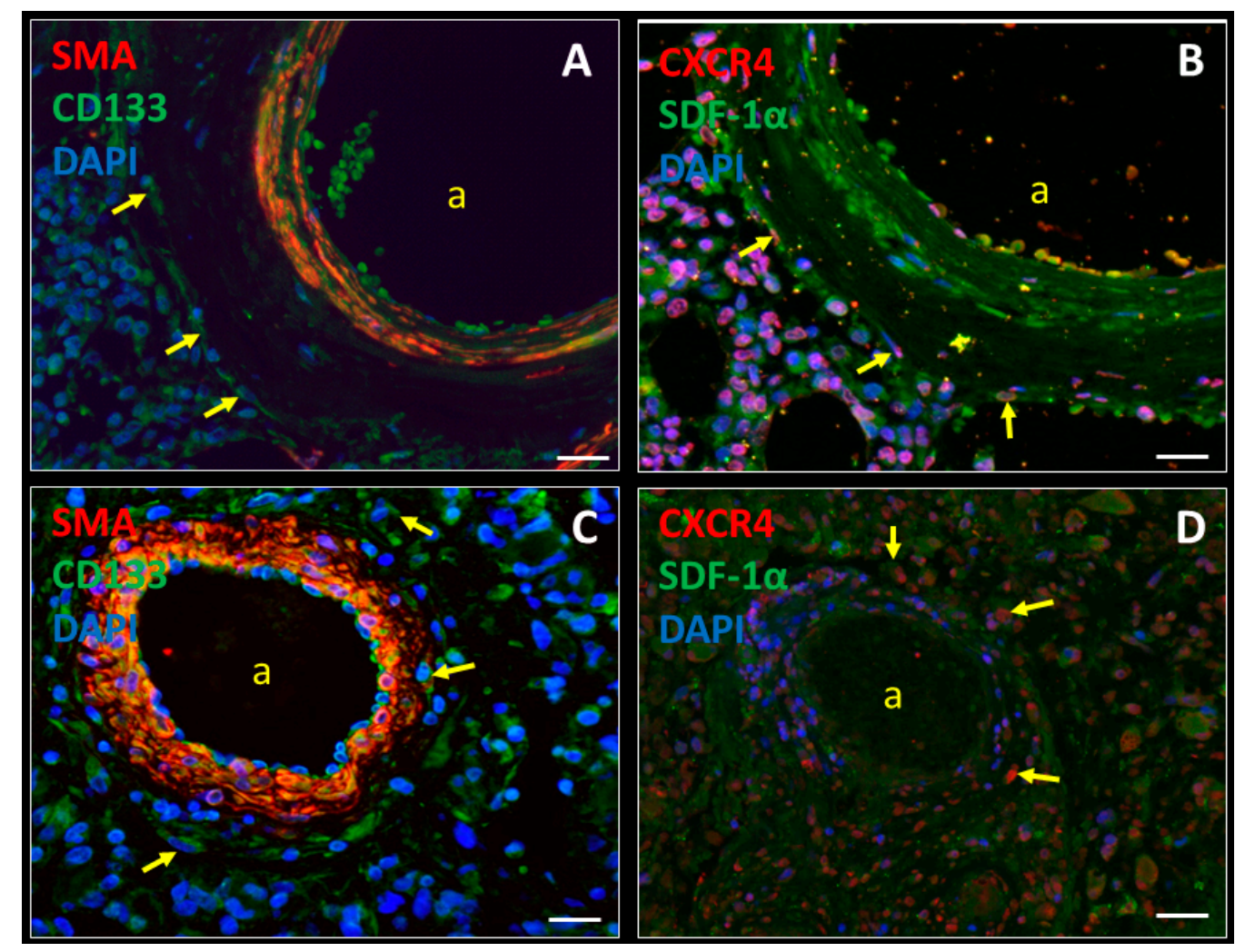

Figure 1. Immunofluorescence staining of a hypoxic peri-arteriolar HSC niche in bone marrow $(\mathbf{A}, \mathbf{B})$ and a hypoxic peri-arteriolar GSC niche in a glioblastoma tumor (C,D). HSCs (A) and GSCs (C) express the stem cell marker CD133 and are localized around the tunica adventitia and the SMA-positive tunica media of an arteriolar wall (a) (A, C, yellow arrows). Receptor CXCR4 is expressed by HSCs (B) and GSCs (D) in SDF- $1 \alpha$-rich niches (B, D, yellow arrows). SDF- $1 \alpha$ is expressed extracellularly and is also expressed by endothelial cells and smooth muscle cells in the tunica media of the arteriolar wall in both HSC niches and GSC niches (B, D). DAPI (blue) is used for nuclear counterstaining. Scale bar $=30 \mu \mathrm{m}$. Abbreviations: CXCR4, C-X-C receptor type 4; DAPI, 4'.6-diamidino-2-phenylindole; GSC, glioblastoma stem cell; HSC, hematopoietic stem cell; SDF- $1 \alpha$, stromal-derived factor- $1 \alpha$; SMA, smooth muscle actin.

From a clinical perspective, our finding that GSC niches in glioblastoma and HSC niches in bone marrow are functionally similar is relevant as it provides a rationale for the repurposing of hematological drugs to the glioblastoma clinic. One such example is the CXCR4 inhibitor plerixafor 
(AMD3100). Plerixafor is an FDA-approved drug for patients who undergo an autologous stem cell transplantation as a treatment for multiple myeloma (MM) or non-Hodgkin's lymphoma. In this setting, plerixafor is used as a HSC mobilizer and optimizes HSC yields after plasmapheresis, which results in a better clinical outcome after stem cell transplantation [20-23].

In addition, plerixafor is currently in clinical trials for the treatment of hematological malignancies themselves, such as acute myeloid leukemia (AML). The rationale behind this possible therapy is that AML cells can relocate to HSC niches in bone marrow via interactions between receptor CXCR4 and chemoattractant SDF- $1 \alpha$ to become slowly-dividing leukemic stem cells (LSCs) that are resistant to chemotherapy. This phenomenon is called "hijacking of HSC niches", which causes relapse in AML patients [24-28]. In vitro studies of a preclinical AML model showed that plerixafor effectively mobilizes slowly-dividing and chemotherapy-resistant LSCs out of HSC niches into the peripheral blood, which results in LSC differentiation and, as a consequence, sensitization to chemotherapy [28-30]. In a non-randomized phase I/II clinical trial including 52 AML patients, the combination of plerixafor and MEC (mitoxantrone, etoposide and cytarabine) chemotherapy was tested [31,32]. A comparison with a historical control cohort showed that the combination of plerixafor and MEC chemotherapy resulted in two-fold increased numbers of AML cells in the peripheral blood and a more than doubled higher overall complete response rate $(46 \%)[31,32]$ compared to MEC chemotherapy alone (21\%) [33]. A phase I clinical trial with a group of 69 AML patients showed that plerixafor can be safely used in combination with the chemotherapeutic agent decitabine, which resulted in mobilization of LSCs out of HSC niches. Whereas the clinical benefits of plerixafor in this setting are uncertain, this was primarily a proof-of-principle study and the data suggest that the therapeutic strategy was successful, as mobilization of LSCs out of the niches into the peripheral blood was achieved [34].

Our point of view is that inhibition of the receptor CXCR4 is a promising approach to enable GSC/LSC mobilization out of their protective niches, which results in GSC/LSC differentiation and proliferation and thereby sensitization to therapy.

Because of the homology of the hypoxic peri-arteriolar HSC niches in bone marrow and the hypoxic peri-arteriolar GSC niches in glioblastoma tumors, we postulate the hypothesis that plerixafor treatment in combination with standard therapies is beneficial for glioblastoma patients as well. This hypothesis is based on the assumption that plerixafor treatment can mobilize GSCs out of their protective niches, which results in GSC differentiation and their sensitization to radiotherapy and chemotherapy $[8,12,13,15]$. In a single-arm phase I/II clinical trial including 29 glioblastoma patients, intravenous administration of plerixafor was combined with radiotherapy and temozolomide chemotherapy $[35,36]$. In this communication, we compare the patient characteristics of this clinical trial with the patient characteristics and survival outcomes of the most recent landmark clinical trial in newly-diagnosed glioblastoma patients [5]. The clinical trials had highly similar inclusion and exclusion criteria. Compared with the historical control cohort, the plerixafor clinical trial included patients who were slightly older, underwent a gross total resection less often and had worse Karnofsky performance scores (all being detrimental prognostic factors [37]) but a higher proportion of patients had a glioblastoma with an IDH1 mutation (being a positive prognostic factor, Table 1 [37-39]). 
Table 1. Glioblastoma patient demographics.

\begin{tabular}{ccc}
\hline Patient Characteristics & Thomas et al. [36] & Stupp et al. (Historical Control) [5] \\
\hline Age (median) & 60 & 57 \\
IDH status: & & \\
Wild-type & $90 \%$ & $95 \%$ \\
Mutant & $10 \%$ & $5 \%$ \\
MGMT status: & & \\
Methylated & $45 \%$ & $45 \%$ \\
Unmethylated & $55 \%$ & $55 \%$ \\
Extent of resection: & $24 \%$ & $13 \%$ \\
Biopsy & $28 \%$ & $33 \%$ \\
Subtotal resection & $48 \%$ & $54 \%$ \\
Gross total resection & & \\
Karnofsky performance score & $41 \%$ & $32 \%$ \\
$\quad \leq 80$ & $59 \%$ & $65 \%$ \\
$90-100$ &
\end{tabular}

Molecular scores are calculated among patients with available data.

Taken together, we conclude that the patient population from the plerixafor clinical trial has similar prognostic features compared with the historical control cohort, in which a median overall survival of 16.0 months was achieved after treatment with radiotherapy and temozolomide chemotherapy alone. In comparison, the aforementioned plerixafor clinical trial yielded a median overall survival of 21.3 months $[35,36]$. This suggests that plerixafor treatment in combination with radiotherapy can prolong glioblastoma patient survival $[35,40]$. In addition, plerixafor was well tolerated at the highest dose of $400 \mu \mathrm{g} / \mathrm{kg} /$ day with no Common Terminology Criteria for Adverse Events (CTCAE) [41] grade 3 or higher toxicities. The authors of the phase I/II clinical trial postulated the hypothesis that hypoxia-induced SDF- $1 \alpha$ secretion after radiotherapy causes infiltration of bone marrow-derived macrophages/monocytes into the glioblastoma tumor via interactions between SDF- $1 \alpha$ and CXCR4 and/or CXCR7 receptors that are expressed on the macrophages/monocytes, resulting in vasculogenesis and tumor recurrence [42-44]. Therefore, the aim was to block the SDF- $1 \alpha-C X C R 4 / C X C R 7$ pathway using plerixafor to abrogate these phenomena. This strategy is called macrophage exclusion after radiation therapy (MERT) [36]. Elevated plerixafor serum levels, elevated SDF-1 $\alpha$ plasma levels and increased numbers of intravascular bone marrow-derived monocytes/macrophages confirmed CXCR4 blockade in the patients [36]. We suggest that CXCR4 inhibition can facilitate the mobilization of GSCs out of their protective niches as well as the mobilization of macrophages out of the tumor, resulting in a better response to radiotherapy and temozolomide chemotherapy.

In this phase I/II clinical trial, the subventricular zone (SVZ) was not irradiated [36]. The SVZ is localized at the border of the lateral ventricles in the cerebrum, where neural stem cells (NSCs) are maintained in niches. The SVZ is also a preferable site for GSCs, as high levels of SDF-1 $\alpha$ facilitate homing of CXCR4-positive GSCs in the SVZ, where GSCs are protected from the effects of radiotherapy. In mouse models, application of plerixafor as well as SDF- $1 \alpha$-blocking antibodies sensitized SVZ-residing GSCs to radiotherapy $[45,46]$. Therefore, we suggest that in clinical trials, the irradiated area should also include the SVZ region after plerixafor treatment to sensitize SVZ-residing GSCs to radiotherapy as well. In agreement with this hypothesis, a phase II clinical trial that is currently recruiting patients will test whole-brain radiotherapy in combination with temozolomide chemotherapy and plerixafor treatment (ClinicalTrials.gov Identifier: NCT03746080).

Multiple studies have shown that CXCR4 is overexpressed in glioblastoma cells, which is associated with increased invasive behavior of glioblastoma cells towards high SDF- $1 \alpha$ concentrations [47-50]. In a study by Yadav et al. (2016), it was shown that human GSCs express high levels of CXCR4 and are attracted towards human brain microvascular endothelial cells that secrete SDF- $1 \alpha$ in vitro, and peri-vascular invasion of GSCs was observed in mouse models of glioblastoma. Blocking CXCR4, using 
plerixafor as well as shRNA-mediated knockdown of CXCR4, downregulated this invasive behavior of GSCs in mice, which resulted in prolonged median survival. In addition, it was demonstrated that CXCR4 inhibition results in increased sensitivity of GSCs to radiotherapy [48]. Thus, CXCR4 inhibition is a promising approach to downregulate GSC invasion and to sensitize GSCs to standard therapies [47-49,51].

Besides plerixafor, there are also other CXCR4 antagonists that are promising to mobilize GSCs out of their protective niches. The novel experimental CXCR4 antagonist PRX17756 has been shown to actively penetrate the blood-brain barrier and to accelerate GSC differentiation [52,53]. Another promising CXCR4 antagonist is BL-8040, a small synthetic peptide (14 amino acids in size) with high affinity for CXCR4 [54]. Therefore, PRX17756 and BL-8040 should also be tested in clinical trials in glioblastoma patients in combination with radiotherapy and temozolomide.

The role of CXCR4 inhibition was investigated in mouse models of immunotherapy of solid tumors. BL-8040 was used to mobilize immune progenitor cells out of bone marrow to obtain higher amounts of T-cells in the circulation and a better infiltration of the tumor, resulting in more effective immune therapy. This in vivo study showed that the CXCR4 inhibitor BL-8040 may have anti-tumor effects by increasing tumor infiltration of antigen-specific effector T-cells [54]. Besides the most-studied plerixafor, many other CXCR4 antagonists have been applied and tested in various types of cancer (Table 2).

Table 2. Overview of CXCR4 antagonists that have been tested in various types of cancer for their therapeutic power/benefit.

\begin{tabular}{ccc}
\hline CXCR4 Antagonists & Type of Cancer & References \\
AMD3100 & Glioblastoma, breast cancer, \\
(plerixafor) & $\begin{array}{c}\text { cholangiocarcinoma, ovarian cancer, } \\
\text { colorectal cancer, melanoma, AML, }\end{array}$ & {$[55]$} \\
ALL, CML, MM, non- Hodgkin's & \\
AMD3465 & lymphoma, HSC mobilization \\
RCP168 & AML, ALL, breast cancer & {$[55-57]$} \\
PRX17756 & AML & {$[56]$} \\
BL-8040 & Glioblastoma & {$[52,53]$} \\
USL311 & Glioblastoma, MM & {$[54,58]$} \\
Balixafortide & Glioblastoma & ClinicalTrials.gov identifier: \\
BKT140 & Breast cancer & NCT02765165), [59] \\
AMD070 & CML, MM & {$[60]$} \\
LY2624587 & Oral cancer & {$[55,61]$} \\
T140 & Non-Hodgkin's lymphoma, ALL & {$[62]$} \\
TG-0054 & CLL, ALL, MM, SCLC & {$[63]$} \\
POL6326 & CLL, MM & {$[64-66]$} \\
MSX-122 & CLL, MM & {$[67]$} \\
TC14012 & CLL, MM, breast cancer & {$[67]$} \\
TN14003 & CLL & {$[67,68]$} \\
CTCE-9908 & CLL & {$[64]$} \\
CTCE-0021 & H64] \\
CTCE-0214 & HSC mobilization & {$[69-72]$} \\
ATI-2341 & HSC mobilization & {$[73,74]$} \\
\hline
\end{tabular}

Abbreviations: ALL, acute lymphoblastic leukemia; CLL, chronic lymphocytic leukemia; $\mathrm{CML}$, chronic myelogenous leukemia; HSC, hematopoietic stem cell; MM, multiple myeloma; SCLC, small cell lung cancer.

Besides chemoattraction and binding, the SDF- $1 \alpha-$ CXCR4 axis is important for cell survival. GSCs express both SDF-1 $\alpha$ and CXCR4 [12], which induces an autocrine loop, resulting in activation of the PI3K-MAPK-ERK1/2 signaling pathway for cell survival [75]. Thus, apart from mobilization of GSCs out of their niches, the abrogation of the SDF- $1 \alpha-C X C R 4$ axis may also reduce GSC survival [75]. 
Bone marrow-derived mesenchymal stem cells (MSCs) are known to be producers of SDF-1 $\alpha$ [12], infiltrate glioblastoma tumors and have affinity for CD133-positive GSCs [76-79]. Our previous studies have shown that CXCR4-positive MSCs are exclusively localized in both HSC niches in normal bone marrow and GSC niches in glioblastoma tumors [12]. Their exact function in glioblastoma tumors is not fully understood. However, our unpublished data suggest that MSCs are involved in attraction and retention of CXCR4-positive GSCs in protective niches. Therefore, plerixafor may also be useful to disrupt interactions between GSCs and MSCs in peri-arteriolar GSC niches.

In conclusion, our hypotheses are that plerixafor and other CXCR4 antagonists are promising as GSC/LSC mobilizers and therapy sensitizers, because they can induce GSC/LSC differentiation into rapidly-dividing progenitor cells that are more vulnerable to chemotherapy and radiotherapy. In addition, SDF-1 $\alpha-$ CXCR4 inhibition can reduce the pro-cell survival effects in GSCs/LSCs.

Author Contributions: Conceptualization, V.V.V.H., C.J.F.V.N.; investigation, V.V.V.H., C.J.F.V.N., R.J.M.; writing - original draft preparation, V.V.V.H., C.J.F.V.N., R.J.M.; writing—review and editing, V.V.V.H., C.J.F.V.N., R.J.M.; supervision, R.J.M.; funding acquisition, C.J.F.V.N., R.J.M. All authors have read and agreed to the published version of the manuscript.

Funding: This study was financially supported by the Dutch Cancer Society (KWF; UVA 2014-6839 and UVA 2016. 1-10460), and R.J.M. was supported by the Fondation pour la Recherche Nuovo-Soldati 2019.

Conflicts of Interest: The authors declare no conflict of interest. The authors declare that the research has been conducted in the absence of any commercial or financial relationships that could be construed as a potential conflict of interest.

\section{References}

1. Stupp, R.; Hegi, M.E.; Mason, W.P.; van den Bent, M.J.; Taphoorn, M.J.; Janzer, R.C.; Ludwin, S.K.; Allgeier, A.; Fisher, B.; Belanger, K.; et al. Effects of radiotherapy with concomitant and adjuvant temozolomide versus radiotherapy alone on survival in glioblastoma in a randomised phase III study: 5-year analysis of the EORTC-NCIC trial. Lancet Oncol. 2009, 10, 459-466. [CrossRef]

2. Stupp, R.; Mason, W.P.; van den Bent, M.J.; Weller, M.; Fisher, B.; Taphoorn, M.J.; Belanger, K.; Brandes, A.A.; Marosi, C.; Bogdahn, U.; et al. Radiotherapy plus concomitant and adjuvant temozolomide for glioblastoma. N. Engl. J. Med. 2005, 352, 987-996. [CrossRef] [PubMed]

3. Thomas, A.A.; Brennan, C.W.; DeAngelis, L.M.; Omuro, A.M. Emerging therapies for glioblastoma. JAMA Neurol. 2014, 71, 1437-1444. [CrossRef] [PubMed]

4. Wen, P.Y.; Kesari, S. Malignant gliomas in adults. N. Engl. J. Med. 2008, 359, 492-507. [CrossRef]

5. Stupp, R.; Taillibert, S.; Kanner, A.; Read, W.; Steinberg, D.; Lhermitte, B.; Toms, S.; Idbaih, A.; Ahluwalia, M.S.; Fink, K.; et al. Effect of tumor-treating fields plus maintenance temozolomide vs maintenance temozolomide alone on survival in patients with glioblastoma: A randomized clinical trial. JAMA 2017, 318, 2306-2316. [CrossRef]

6. Singh, S.K.; Hawkins, C.; Clarke, I.D.; Squire, J.A.; Bayani, J.; Hide, T.; Henkelman, R.M.; Cusimano, M.D.; Dirks, P.B. Identification of human brain tumour initiating cells. Nature 2004, 432, 396-401. [CrossRef]

7. Breznik, B.; Limback, C.; Porcnik, A.; Blejec, A.; Krajnc, M.K.; Bosnjak, R.; Kos, J.; Van Noorden, C.J.F.; Lah, T.T. Localization patterns of cathepsins $\mathrm{K}$ and $\mathrm{X}$ and their predictive value in glioblastoma. Radiol. Oncol. 2018, 52, 433-442. [CrossRef]

8. Aderetti, D.A.; Hira, V.V.V.; Molenaar, R.J.; Van Noorden, C.J.F. The hypoxic peri-arteriolar glioma stem cell niche, an integrated concept of five types of niches in human glioblastoma. Biochim. Biophys. Acta Rev. Cancer 2018, 1869, 346-354. [CrossRef]

9. Singh, S.K.; Clarke, I.D.; Terasaki, M.; Bonn, V.E.; Hawkins, C.; Squire, J.; Dirks, P.B. Identification of a cancer stem cell in human brain tumors. Cancer Res. 2003, 63, 5821-5828.

10. Dirkse, A.; Golebiewska, A.; Buder, T.; Nazarov, P.V.; Muller, A.; Poovathingal, S.; Brons, N.H.C.; Leite, S.; Sauvageot, N.; Sarkisjan, D.; et al. Stem cell-associated heterogeneity in glioblastoma results from intrinsic tumor plasticity shaped by the microenvironment. Nat. Commun. 2019, 10, 1787. [CrossRef]

11. Gimple, R.C.; Bhargava, S.; Dixit, D.; Rich, J.N. Glioblastoma stem cells: Lessons from the tumor hierarchy in a lethal cancer. Genes Dev. 2019, 33, 591-609. [CrossRef] [PubMed] 
12. Hira, V.V.V.; Breznik, B.; Vittori, M.; Loncq de Jong, A.; Mlakar, J.; Oostra, R.J.; Khurshed, M.; Molenaar, R.J.; Lah, T.; Van Noorden, C.J.F. Similarities between stem cell niches in glioblastoma and bone marrow: Rays of hope for novel treatment strategies. J. Histochem. Cytochem. 2019, 68, 33-57. [CrossRef] [PubMed]

13. Hira, V.V.V.; Wormer, J.R.; Kakar, H.; Breznik, B.; van der Swaan, B.; Hulsbos, R.; Tigchelaar, W.; Tonar, Z.; Khurshed, M.; Molenaar, R.J.; et al. Periarteriolar glioblastoma stem cell niches express bone marrow hematopoietic stem cell niche proteins. J. Histochem. Cytochem. 2018, 63, 155-173. [CrossRef] [PubMed]

14. Hira, V.V.; Ploegmakers, K.J.; Grevers, F.; Verbovsek, U.; Silvestre-Roig, C.; Aronica, E.; Tigchelaar, W.; Turnsek, T.L.; Molenaar, R.J.; Van Noorden, C.J. CD133+ and nestin+ glioma stem-like cells reside around CD31+ arterioles in niches that express SDF-1alpha, CXCR4, osteopontin and cathepsin K. J. Histochem. Cytochem. 2015, 63, 481-493. [CrossRef]

15. Hira, V.V.V.; Aderetti, D.A.; Van Noorden, C.J.F. Glioma stem cell niches in human glioblastoma are periarteriolar. J. Histochem Cytochem 2018, 66, 349-358. [CrossRef]

16. Zagzag, D.; Esencay, M.; Mendez, O.; Yee, H.; Smirnova, I.; Huang, Y.; Chiriboga, L.; Lukyanov, E.; Liu, M.; Newcomb, E.W. Hypoxia- and vascular endothelial growth factor-induced stromal cell-derived factor-1alpha/CXCR4 expression in glioblastomas: One plausible explanation of Scherer's structures. Am. J. Pathol. 2008, 173, 545-560. [CrossRef]

17. Zagzag, D.; Lukyanov, Y.; Lan, L.; Ali, M.A.; Esencay, M.; Mendez, O.; Yee, H.; Voura, E.B.; Newcomb, E.W. Hypoxia-inducible factor 1 and VEGF upregulate CXCR4 in glioblastoma: Implications for angiogenesis and glioma cell invasion. Lab. Invest. 2006, 86, 1221-1232. [CrossRef]

18. Motegi, H.; Kamoshima, Y.; Terasaka, S.; Kobayashi, H.; Houkin, K. Type 1 collagen as a potential niche component for CD133-positive glioblastoma cells. Neuropathology 2014, 34, 378-385. [CrossRef]

19. Abdelrahman, A.E.; Ibrahim, H.M.; Elsebai, E.A.; Ismail, E.I.; Elmesallamy, W. The clinicopathological significance of CD133 and Sox2 in astrocytic glioma. Cancer Biomark. 2018, 23, 391-403. [CrossRef]

20. DiPersio, J.F.; Micallef, I.N.; Stiff, P.J.; Bolwell, B.J.; Maziarz, R.T.; Jacobsen, E.; Nademanee, A.; McCarty, J.; Bridger, G.; Calandra, G.; et al. Phase III prospective randomized double-blind placebo-controlled trial of plerixafor plus granulocyte colony-stimulating factor compared with placebo plus granulocyte colony-stimulating factor for autologous stem-cell mobilization and transplantation for patients with non-Hodgkin's lymphoma. J. Clin. Oncol. 2009, 27, 4767-4773. [CrossRef]

21. DiPersio, J.F.; Stadtmauer, E.A.; Nademanee, A.; Micallef, I.N.; Stiff, P.J.; Kaufman, J.L.; Maziarz, R.T.; Hosing, C.; Fruehauf, S.; Horwitz, M.; et al. Plerixafor and G-CSF versus placebo and G-CSF to mobilize hematopoietic stem cells for autologous stem cell transplantation in patients with multiple myeloma. Blood 2009, 113, 5720-5726. [CrossRef] [PubMed]

22. Stiff, P.; Micallef, I.; McCarthy, P.; Magalhaes-Silverman, M.; Weisdorf, D.; Territo, M.; Badel, K.; Calandra, G. Treatment with plerixafor in non-Hodgkin's lymphoma and multiple myeloma patients to increase the number of peripheral blood stem cells when given a mobilizing regimen of G-CSF: Implications for the heavily pretreated patient. Biol. Blood Marrow Transplant. 2009, 15, 249-256. [CrossRef] [PubMed]

23. Andritsos, L.A.; Huang, Y.; Abraham, I.; Huff, K.; Scrape, S.R.; Fan, T.; Alkhatib, N.; Hofmeister, C.C.; Drea, E.; McBride, A. Clinical and cost outcomes of pre-emptive plerixafor administration in patients with multiple myeloma undergoing stem cell mobilization. Leuk. Res. 2019, 85, 106215. [CrossRef] [PubMed]

24. Hira, V.V.V.; Van Noorden, C.J.F.; Carraway, H.E.; Maciejewski, J.P.; Molenaar, R.J. Novel therapeutic strategies to target leukemic cells that hijack compartmentalized continuous hematopoietic stem cell niches. Biochim. Biophys. Acta Rev. Cancer 2017, 1868, 183-198. [CrossRef] [PubMed]

25. Cogle, C.R.; Bosse, R.C.; Brewer, T.; Migdady, Y.; Shirzad, R.; Kampen, K.R.; Saki, N. Acute myeloid leukemia in the vascular niche. Cancer Lett. 2015, 380, 552-560. [CrossRef]

26. Cogle, C.R.; Saki, N.; Khodadi, E.; Li, J.; Shahjahani, M.; Azizidoost, S. Bone marrow niche in the myelodysplastic syndromes. Leuk Res. 2015, 39, 1020-1027. [CrossRef]

27. Hanekamp, D.; Cloos, J.; Schuurhuis, G.J. Leukemic stem cells: Identification and clinical application. Int. J. Hematol. 2017, 105, 549-557. [CrossRef]

28. Bernasconi, P.; Borsani, O. Targeting leukemia stem cell-niche dynamics: A new challenge in AML treatment. J. Oncol. 2019, 2019, 8323592. [CrossRef]

29. Nervi, B.; Ramirez, P.; Rettig, M.P.; Uy, G.L.; Holt, M.S.; Ritchey, J.K.; Prior, J.L.; Piwnica-Worms, D.; Bridger, G.; Ley, T.J.; et al. Chemosensitization of acute myeloid leukemia (AML) following mobilization by the CXCR4 antagonist AMD3100. Blood 2009, 113, 6206-6214. [CrossRef] 
30. Zeng, Z.; Shi, Y.X.; Samudio, I.J.; Wang, R.Y.; Ling, X.; Frolova, O.; Levis, M.; Rubin, J.B.; Negrin, R.R.; Estey, E.H.; et al. Targeting the leukemia microenvironment by CXCR4 inhibition overcomes resistance to kinase inhibitors and chemotherapy in AML. Blood 2009, 113, 6215-6224. [CrossRef]

31. Uy, G.L.; Rettig, M.P.; Motabi, I.H.; McFarland, K.; Trinkaus, K.M.; Hladnik, L.M.; Kulkarni, S.; Abboud, C.N.; Cashen, A.F.; Stockerl-Goldstein, K.E.; et al. A phase 1/2 study of chemosensitization with the CXCR4 antagonist plerixafor in relapsed or refractory acute myeloid leukemia. Blood 2012, 119, 3917-3924. [CrossRef] [PubMed]

32. Uy, G.L.; Rettig, M.P.; Stone, R.M.; Konopleva, M.Y.; Andreeff, M.; McFarland, K.; Shannon, W.; Fletcher, T.R.; Reineck, T.; Eades, W.; et al. A phase 1/2 study of chemosensitization with plerixafor plus G-CSF in relapsed or refractory acute myeloid leukemia. Blood Cancer J. 2017, 7, e542. [CrossRef] [PubMed]

33. Greenberg, P.L.; Lee, S.J.; Advani, R.; Tallman, M.S.; Sikic, B.I.; Letendre, L.; Dugan, K.; Lum, B.; Chin, D.L.; Dewald, G.; et al. Mitoxantrone, etoposide, and cytarabine with or without valspodar in patients with relapsed or refractory acute myeloid leukemia and high-risk myelodysplastic syndrome: A phase III trial (E2995). J. Clin. Oncol. 2004, 22, 1078-1086. [CrossRef]

34. Roboz, G.J.; Ritchie, E.K.; Dault, Y.; Lam, L.; Marshall, D.C.; Cruz, N.M.; Hsu, H.-T.C.; Hassane, D.C.; Christos, P.J.; Ippoliti, C.; et al. Phase I trial of plerixafor combined with decitabine in newly diagnosed older patients with acute myeloid leukemia. J. Haematol. 2018, 103, 1308-1316. [CrossRef]

35. Giordano, F.A.; Link, B.; Glas, M.; Herrlinger, U.; Wenz, F.; Umansky, V.; Brown, J.M.; Herskind, C. Targeting the post-irradiation tumor microenvironment in glioblastoma via inhibition of CXCL12. Cancers 2019, 11, 272. [CrossRef]

36. Thomas, R.P.; Nagpal, S.; Iv, M.; Soltys, S.G.; Bertrand, S.; Pelpola, J.S.; Ball, R.; Yang, J.; Sundaram, V.; Lavezo, J.; et al. Macrophage exclusion after radiation therapy (MERT): A first in human phase I/II trial using a CXCR4 inhibitor in glioblastoma. Clin. Cancer Res. 2019, 25, 6948-6957. [CrossRef]

37. Molenaar, R.J.; Verbaan, D.; Lamba, S.; Zanon, C.; Jeuken, J.W.; Boots-Sprenger, S.H.; Wesseling, P.; Hulsebos, T.J.; Troost, D.; van Tilborg, A.A.; et al. The combination of IDH1 mutations and MGMT methylation status predicts survival in glioblastoma better than either IDH1 or MGMT alone. Neuro Oncol. 2014, 16, 1263-1273. [CrossRef]

38. Molenaar, R.J.; Radivoyevitch, T.; Maciejewski, J.P.; Van Noorden, C.J.; Bleeker, F.E. The driver and passenger effects of isocitrate dehydrogenase 1 and 2 mutations in oncogenesis and survival prolongation. Biochim. Biophys. Acta Rev. Cancer 2014, 1846, 326-341. [CrossRef]

39. Molenaar, R.J.; Maciejewski, J.P.; Wilmink, J.W.; Van Noorden, C.J.F. Wild-type and mutated IDH1/2 enzymes and therapy responses. Oncogene 2018, 37, 1949-1960. [CrossRef]

40. Shumilov, E.; Novak, U.; Jeker, B.; Mansouri Taleghani, B.; Bacher, U.; Pabst, T. Hematopoietic stem cell mobilization with plerixafor is safe and effective in poorly mobilizing acute myeloid leukemia patients. Hemasphere 2019, 3, e176. [CrossRef]

41. National Cancer Institute (U.S.). Common Terminology Criteria for Adverse Events (CTCAE); U.S. Department of Health and Human Services, National Institutes of Health, National Cancer Institute: Bethesda, MD, USA, 2009; p. 194.

42. Brown, J.M. Vasculogenesis: A crucial player in the resistance of solid tumours to radiotherapy. Br. J. Radiol. 2014, 87, 20130686. [CrossRef]

43. Russell, J.S.; Brown, J.M. The irradiated tumor microenvironment: Role of tumor-associated macrophages in vascular recovery. Front. Physiol. 2013, 4, 157. [CrossRef] [PubMed]

44. Tseng, D.; Vasquez-Medrano, D.A.; Brown, J.M. Targeting SDF-1/CXCR4 to inhibit tumour vasculature for treatment of glioblastomas. Br. J. Cancer 2011, 104, 1805-1809. [CrossRef]

45. Goffart, N.; Kroonen, J.; Di Valentin, E.; Dedobbeleer, M.; Denne, A.; Martinive, P.; Rogister, B. Adult mouse subventricular zones stimulate glioblastoma stem cells specific invasion through CXCL12/CXCR4 signaling. Neuro Oncol. 2015, 17, 81-94. [CrossRef] [PubMed]

46. Goffart, N.; Lombard, A.; Lallemand, F.; Kroonen, J.; Nassen, J.; Di Valentin, E.; Berendsen, S.; Dedobbeleer, M.; Willems, E.; Robe, P.; et al. CXCL12 mediates glioblastoma resistance to radiotherapy in the subventricular zone. Neuro Oncol. 2017, 19, 66-77. [CrossRef] [PubMed]

47. Ehtesham, M.; Winston, J.A.; Kabos, P.; Thompson, R.C. CXCR4 expression mediates glioma cell invasiveness. Oncogene 2006, 25, 2801-2806. [CrossRef] 
48. Yadav, V.N.; Zamler, D.; Baker, G.J.; Kadiyala, P.; Erdreich-Epstein, A.; DeCarvalho, A.C.; Mikkelsen, T.; Castro, M.G.; Lowenstein, P.R. CXCR4 increases in-vivo glioma perivascular invasion, and reduces radiation induced apoptosis: A genetic knockdown study. Oncotarget 2016, 7, 83701-83719. [CrossRef]

49. Cornelison, R.C.; Brennan, C.E.; Kingsmore, K.M.; Munson, J.M. Convective forces increase CXCR4-dependent glioblastoma cell invasion in GL261 murine model. Sci. Rep. 2018, 8, 17057. [CrossRef]

50. Stevenson, C.B.; Ehtesham, M.; McMillan, K.M.; Valadez, J.G.; Edgeworth, M.L.; Price, R.R.; Abel, T.W.; Mapara, K.Y.; Thompson, R.C. CXCR4 expression is elevated in glioblastoma multiforme and correlates with an increase in intensity and extent of peritumoral T2-weighted magnetic resonance imaging signal abnormalities. Neurosurgery 2008, 63, 560-569. [CrossRef]

51. Bian, X.W.; Yang, S.X.; Chen, J.H.; Ping, Y.F.; Zhou, X.D.; Wang, Q.L.; Jiang, X.F.; Gong, W.; Xiao, H.L.; Du, L.L.; et al. Preferential expression of chemokine receptor CXCR4 by highly malignant human gliomas and its association with poor patient survival. Neurosurgery 2007, 61, 570-578. [CrossRef]

52. Gravina, G.L.; Mancini, A.; Colapietro, A.; Vitale, F.; Vetuschi, A.; Pompili, S.; Rossi, G.; Marampon, F.; Richardson, P.J.; Patient, L.; et al. The novel CXCR4 antagonist, PRX177561, reduces tumor cell proliferation and accelerates cancer stem cell differentiation in glioblastoma preclinical models. Tumour Biol. 2017, 39, 1010428317695528. [CrossRef]

53. Gravina, G.L.; Mancini, A.; Marampon, F.; Colapietro, A.; Delle Monache, S.; Sferra, R.; Vitale, F.; Richardson, P.J.; Patient, L.; Burbidge, S.; et al. The brain-penetrating CXCR4 antagonist, PRX177561, increases the antitumor effects of bevacizumab and sunitinib in preclinical models of human glioblastoma. J. Hematol. Oncol. 2017, 10, 5. [CrossRef]

54. Gaur, P.; Verma, V.; Gupta, S.; Sorani, E.; Haras, A.V.; Oberkovitz, G.; Peled, A.; Khleif, S. CXCR4 antagonist (BL-8040) to enhance antitumor effects by increasing tumor infiltration of antigen-specific effector T-cells. J. Clin. Oncol. 2018, 36, 73. [CrossRef]

55. Burger, J.A.; Peled, A. CXCR4 antagonists: Targeting the microenvironment in leukemia and other cancers. Leukemia 2009, 23, 43-52. [CrossRef]

56. Zeng, Z.; Samudio, I.J.; Munsell, M.; An, J.; Huang, Z.; Estey, E.; Andreeff, M.; Konopleva, M. Inhibition of CXCR4 with the novel RCP168 peptide overcomes stroma-mediated chemoresistance in chronic and acute leukemias. Mol. Cancer Ther. 2006, 5, 3113-3121. [CrossRef]

57. Zhang, J.; Pang, Y.; Xie, T.; Zhu, L. CXCR4 antagonism in combination with IDO1 inhibition weakens immune suppression and inhibits tumor growth in mouse breast cancer bone metastases. Onco. Targets Ther. 2019, 12, 4985-4992. [CrossRef]

58. Crees, Z.D.; Stockerl-Goldstein, K.; Vainstein, A.; Chen, H.; DiPersio, J.F. GENESIS: Phase III trial evaluating BL-8040 + G-CSF to mobilize hematopoietic cells for autologous transplant in myeloma. Future Oncol. 2019, 15, 3555-3563. [CrossRef]

59. Shergalis, A.; Bankhead, A., 3rd; Luesakul, U.; Muangsin, N.; Neamati, N. Current challenges and opportunities in treating glioblastoma. Pharmacol. Rev. 2018, 70, 412-445. [CrossRef]

60. Cortes, J.; Holgado, E.; Perez-Garcia, J. CXCR4 antagonists for treatment of breast cancer. Oncotarget 2018, 9 , 33442-33443. [CrossRef]

61. Beider, K.; Darash-Yahana, M.; Blaier, O.; Koren-Michowitz, M.; Abraham, M.; Wald, H.; Wald, O.; Galun, E.; Eizenberg, O.; Peled, A.; et al. Combination of imatinib with CXCR4 antagonist BKT140 overcomes the protective effect of stroma and targets CML in vitro and in vivo. Mol. Cancer Ther. 2014, 13, 1155-1169. [CrossRef]

62. Uchida, D.; Kuribayashi, N.; Kinouchi, M.; Sawatani, Y.; Shimura, M.; Mori, T.; Hasegawa, T.; Miyamoto, Y.; Kawamata, H. Effect of a novel orally bioavailable CXCR4 inhibitor, AMD070, on the metastasis of oral cancer cells. Oncol. Rep. 2018, 40, 303-308. [CrossRef]

63. Peng, S.B.; Zhang, X.; Paul, D.; Kays, L.M.; Ye, M.; Vaillancourt, P.; Dowless, M.; Stancato, L.F.; Stewart, J.; Uhlik, M.T.; et al. Inhibition of CXCR4 by LY2624587, a fully humanized anti-CXCR4 antibody induces apoptosis of hematologic malignancies. PLoS ONE 2016, 11, e0150585. [CrossRef]

64. Burger, M.; Hartmann, T.; Krome, M.; Rawluk, J.; Tamamura, H.; Fujii, N.; Kipps, T.J.; Burger, J.A. Small peptide inhibitors of the CXCR4 chemokine receptor (CD184) antagonize the activation, migration, and antiapoptotic responses of CXCL12 in chronic lymphocytic leukemia B cells. Blood 2005, 106, 1824-1830. [CrossRef] 
65. Juarez, J.; Bradstock, K.F.; Gottlieb, D.J.; Bendall, L.J. Effects of inhibitors of the chemokine receptor CXCR4 on acute lymphoblastic leukemia cells in vitro. Leukemia 2003, 17, 1294-1300. [CrossRef]

66. Zannettino, A.C.; Farrugia, A.N.; Kortesidis, A.; Manavis, J.; To, L.B.; Martin, S.K.; Diamond, P.; Tamamura, H.; Lapidot, T.; Fujii, N.; et al. Elevated serum levels of stromal-derived factor-1alpha are associated with increased osteoclast activity and osteolytic bone disease in multiple myeloma patients. Cancer Res. 2005, 65, 1700-1709. [CrossRef]

67. De Nigris, F.; Schiano, C.; Infante, T.; Napoli, C. CXCR4 inhibitors: Tumor vasculature and therapeutic challenges. Recent Pat. Anticancer Drug Discov. 2012, 7, 251-264. [CrossRef]

68. Liang, Z.; Zhan, W.; Zhu, A.; Yoon, Y.; Lin, S.; Sasaki, M.; Klapproth, J.M.; Yang, H.; Grossniklaus, H.E.; Xu, J.; et al. Development of a unique small molecule modulator of CXCR4. PLoS ONE 2012, 7, e34038. [CrossRef]

69. Lee, H.H.; Bellat, V.; Law, B. Chemotherapy induces adaptive drug resistance and metastatic potentials via phenotypic CXCR4-expressing cell state transition in ovarian cancer. PLoS ONE 2017, 12, e0171044. [CrossRef]

70. Gravina, G.L.; Mancini, A.; Muzi, P.; Ventura, L.; Biordi, L.; Ricevuto, E.; Pompili, S.; Mattei, C.; Di Cesare, E.; Jannini, E.A.; et al. CXCR4 pharmacogical inhibition reduces bone and soft tissue metastatic burden by affecting tumor growth and tumorigenic potential in prostate cancer preclinical models. Prostate 2015, 75, 1227-1246. [CrossRef]

71. Singh, B.; Cook, K.R.; Martin, C.; Huang, E.H.; Mosalpuria, K.; Krishnamurthy, S.; Cristofanilli, M.; Lucci, A. Evaluation of a CXCR4 antagonist in a xenograft mouse model of inflammatory breast cancer. Clin. Exp. Metastasis 2010, 27, 233-240. [CrossRef]

72. Drenckhan, A.; Kurschat, N.; Dohrmann, T.; Raabe, N.; Koenig, A.M.; Reichelt, U.; Kaifi, J.T.; Izbicki, J.R.; Gros, S.J. Effective inhibition of metastases and primary tumor growth with CTCE-9908 in esophageal cancer. J. Surg. Res. 2013, 182, 250-256. [CrossRef] [PubMed]

73. Ratajczak, M.Z.; Kim, C. The use of chemokine receptor agonists in stem cell mobilization. Expert Opin. Biol. Ther. 2012, 12, 287-297. [CrossRef] [PubMed]

74. Pelus, L.M.; Bian, H.; Fukuda, S.; Wong, D.; Merzouk, A.; Salari, H. The CXCR4 agonist peptide, CTCE-0021, rapidly mobilizes polymorphonuclear neutrophils and hematopoietic progenitor cells into peripheral blood and synergizes with granulocyte colony-stimulating factor. Exp. Hematol. 2005, 33, 295-307. [CrossRef] [PubMed]

75. Wurth, R.; Bajetto, A.; Harrison, J.K.; Barbieri, F.; Florio, T. CXCL12 modulation of CXCR4 and CXCR7 activity in human glioblastoma stem-like cells and regulation of the tumor microenvironment. Front. Cell Neurosci. 2014, 8, 144. [CrossRef]

76. Rodini, C.O.; Goncalves da Silva, P.B.; Assoni, A.F.; Carvalho, V.M.; Okamoto, O.K. Mesenchymal stem cells enhance tumorigenic properties of human glioblastoma through independent cell-cell communication mechanisms. Oncotarget 2018, 9, 24766-24777. [CrossRef]

77. Breznik, B.; Motaln, H.; Vittori, M.; Rotter, A.; Lah Turnsek, T. Mesenchymal stem cells differentially affect the invasion of distinct glioblastoma cell lines. Oncotarget 2017, 8, 25482-25499. [CrossRef]

78. Pavon, L.F.; Sibov, T.T.; de Souza, A.V.; da Cruz, E.F.; Malheiros, S.M.F.; Cabral, F.R.; de Souza, J.G.; Boufleur, P.; de Oliveira, D.M.; de Toledo, S.R.C.; et al. Tropism of mesenchymal stem cell toward CD133(+) stem cell of glioblastoma in vitro and promote tumor proliferation in vivo. Stem Cell Res. Ther. 2018, 9, 310. [CrossRef]

79. Motaln, H.; Gruden, K.; Hren, M.; Schichor, C.; Primon, M.; Rotter, A.; Lah, T.T. Human mesenchymal stem cells exploit the immune response mediating chemokines to impact the phenotype of glioblastoma. Cell Transplant. 2012, 21, 1529-1545. [CrossRef]

(C) 2020 by the authors. Licensee MDPI, Basel, Switzerland. This article is an open access article distributed under the terms and conditions of the Creative Commons Attribution (CC BY) license (http://creativecommons.org/licenses/by/4.0/). 